\title{
Need for the Determination of the Nigerian Fault Lines
}

\author{
ONWUZULIGBO, Chukwubueze U.* and ONO, Matthew N. \\ Department of Surveying and Geoinformatics, Nnamdi Azikiwe University, Awka, Nigeria
}

\begin{abstract}
Earthquakes and Tremors are Tectonic activities traced to Crustal Motions with roots in the Continental Drift Theory. These activities occur mostly at Plate Boundaries and along or close to Fault Lines. Nigeria was erroneously considered aseismic in the past, but studies have shown that Nigeria was never aseismic as information on different Tremors and Earthquakes abound. The recent occurrences of Tremors in Abuja, the Nation's Capital, call for a serious attention towards the definition of the Nigerian Fault Lines. An attempt towards the determination of the Fault Lines is made, using the Non-Geodetic and Geodetic Methods. The Non-Geodetic Method Seeks to connect the Epicenters of different Earthquakes and Tremors on record, in order to present a possible set of Fault Lines. Three Fault Lines, The Western Nigeria Fault Line, the Mid Nigeria Fault Line and the Eastern Nigeria Fault Lines were proposed. The Geodetic Method adopted the use of archived GNSS data from the Nigerian CORS stations between 2012 and 2014. Fourteen sites, ABUZ, BKFP, GCCT, CLBR, FPNO, FUTA, FUTY, GEMB, HUKP, MDGR, OSGF, RUST, ULAG and UNEC, were used for this experiment, and ten IGS stations, DEAR, ABPO, RAMO, DARK, MELI, ASCG, MOIU, ZAMB, NOT1, BHR4, were used for Network Stabilization in the experiment conducted with the GAMIT/GLOBK Software. The Mean Horizontal Velocity of Nigeria for the period was $22.5625 \pm 0.32583 \mathrm{~mm} / \mathrm{yr}$ East, $18.93 \pm 0.23417 \mathrm{~mm} / \mathrm{yr}$ North, found to agree with Bawa, Ojigi and Dodo (2018) and Altamimi et al (2011). The Analysis of the Position Solution, showed that stations along a particular line, share similar direction of motion, which agrees with the Non-Geodetic Proposal. It was recommended that in order to adequately and accurately determine the Fault System in Nigeria, about three times the existing number of CORS Stations must be established, and their data made readily available to researchers.
\end{abstract}

Keywords: Earthquakes, Tremors, Fault Lines, GAMIT/GLOBK

DOI: $10.7176 / \mathrm{JEES} / 11-10-05$

Publication date:October $31^{\text {st }} 2021$

\subsection{Introduction}

Earthquakes and tremors are some of the most frequent natural disasters that threaten the lives and property of man in the earth today. The cause of these disasters have their roots explained in the continental drift theory (Ingolfsson, 2008) Researches have been found to agree that they are known to have their epicenters along plate boundaries and fault lines (Akkar et al, 2010, Reilinger and McClusky 2011, Cetin et al, 2014).The human and economic loss caused by these activities is enormous. According to Hackl, Malservisi and Wdowinski(2009), the 1994, $\mathrm{Mw}=6.7$ Northridge and the 1995, $\mathrm{Mw}=6.8$ Kobe earthquakes caused unprecedented damage of more than US $\$ 40$ billion and US \$100 billion, respectively. Also Akkar et al (2010) recorded that forty-two people lost their lives and 137 were injured during the $\mathrm{M}_{\mathrm{W}}=6.1$ earthquake that occurred in the Elazığ region of Eastern Turkey on 8 March 2010 at 02:32:34 UTC. Furthermore, Nwankwoala and Orji (2018) indicated the extent of damages felt in the events of different occurrences in Nigeria.

Nigeria lies on the eastern flank of the Atlantic Ocean, and according to Akpan and Yakubu(2010), the Atlantic Ocean margins have been opening consistently since Jurassic times. Unlike the Pacific Ocean margins which are characterized by subduction tectonics and occurrence of devastating earthquakes (convergent boundary), the Atlantic margins are generally thought to be quiet (divergent boundary) and as a result, there was little consciousness and preparedness for earthquake occurrences and mitigation in Nigeria. Against the backdrop of being perceived as aseismic, there have been several earthquakes and tremors in Nigeria (Akpan and Yakubu, 2010, Tsalha et al, 2015, Afegbua in Orakpo, 2017, Nwankwoala and Orji, 2018). Table 1 illustrates the reported cases of earthquakes and tremors in Nigeria, locations they were felt, the magnitude or intensity picked/felt and their probable epicenters.

With the attendant loss of lives and property involved in the events of these natural disasters, it is highly important and should be paramount in the priority list of any disaster mitigation and control agency that the fault lines be defined, monitored and be considered in the planning and siting of major developmental projects. The definition of these fault lines, therefore, cannot be over emphasized. It is only the first step towards the reduction of the high risks of loss of lives and properties on the event of these disasters. 
Table 1: Historical Record of Earthquakes and Tremors in Nigeria from 1900 till Date

\begin{tabular}{|c|c|c|c|c|c|c|c|}
\hline $\mathbf{S} / \mathbf{N}$ & DATE (m/d/yy) & TOWN & STATE & INTENSITY/MAGNITUDE & $\begin{array}{l}\text { PROBABLE } \\
\text { EPICENTER }\end{array}$ & LONG & LAT \\
\hline 1 & $4 / 16 / 1905$ & Warri, Ohafia & $\begin{array}{l}\text { Delta, } \\
\text { Abia }\end{array}$ & & & $\begin{array}{l}05 \quad 45^{\prime} \\
0747^{\prime}\end{array}$ & $\begin{array}{ll}05 & 31^{\prime} \\
05 & 37^{\prime}\end{array}$ \\
\hline 2 & $6 / 22 / 1939$ & $\begin{array}{l}\text { Lagos, Ibadan, Ile- } \\
\text { Ife }\end{array}$ & $\begin{array}{l}\text { Lagos, } \\
\text { Oyo, } \\
\text { Osun }\end{array}$ & $6.5(\mathrm{ML})$ & $\begin{array}{l}\text { Akwapim Fault in } \\
\text { Ghana }\end{array}$ & $0323^{\prime}$ & $0630^{\prime}$ \\
\hline 3 & $5 / 1 / 1905$ & Ibadan & Oyo & & Close to Ibadan & & \\
\hline 4 & $5 / 2 / 1905$ & Ibadan & Oyo & & Close to Ibadan & & \\
\hline 5 & $7 / 2 / 1961$ & Ohafia & Abia & & Close to Ohafia & $0747^{\prime}$ & $0537^{\prime}$ \\
\hline 6 & $12 / 21 / 1963$ & Ijebu-Ode & Ogun & $\mathrm{V}$ & Close to Ijebu-Ode & & \\
\hline 7 & $7 / 1 / 1975$ & Dambata & Kano & & & $0831^{\prime}$ & $1225^{\prime}$ \\
\hline 8 & $6 / 3 / 1905$ & Kundunu & Kano & III & & $0824^{\prime}$ & $1148^{\prime}$ \\
\hline 9 & $10 / 16 / 1982$ & Jalingo, Gembu & Taraba & III & $\begin{array}{l}\text { Close to Cameroun } \\
\text { Volcanic Line }\end{array}$ & & \\
\hline 10 & $7 / 12 / 1984$ & Ijebu Remo & Ogun & IV & Close to Ijebu-Ode & & \\
\hline 11 & $7 / 28 / 1984$ & $\begin{array}{l}\text { Ijebu-Ode, Ibadan, } \\
\text { Shagamu, } \\
\text { Abeokuta }\end{array}$ & $\begin{array}{l}\text { Ogun, } \\
\text { Oyo }\end{array}$ & VI & Close to Ijebu-Ode & $0355^{\prime}$ & $648^{\prime}$ \\
\hline 12 & $8 / 2 / 1984$ & $\begin{array}{ll}\text { Ibadan, } & \text { Oyo, } \\
\text { ljebu-Ode, } & \\
\text { Shagamu, } & \\
\text { Abeokuta } \\
\text { Ijebu Remo }\end{array}$ & $\begin{array}{l}\text { Oyo, } \\
\text { Ogun }\end{array}$ & V & Close to Ijebu-Ode & $0322^{\prime}$ & $0711^{\prime}$ \\
\hline 13 & $12 / 8 / 1984$ & Yola & Adamawa & III & $\begin{array}{l}\text { Close to Cameroun } \\
\text { Volcanic Line }\end{array}$ & $1227^{\prime}$ & $914^{\prime}$ \\
\hline 14 & $6 / 18 / 1985$ & Kombani-Yaya & Bauchi & $\mathrm{V}$ & Kombani-Yaya & $1100^{\prime}$ & $1002^{\prime}$ \\
\hline 15 & $6 / 8 / 1905$ & Obi & Benue & III & Close to Obi & $0846^{\prime}$ & $0822^{\prime}$ \\
\hline 16 & $6 / 8 / 1905$ & Abeokuta & Ogun & & & & \\
\hline 17 & $1 / 27 / 1987$ & Gembu & Taraba & $\mathrm{V}$ & $\begin{array}{l}\text { Close to Cameroun } \\
\text { Volcanic Line }\end{array}$ & $1115^{\prime}$ & $0642^{\prime}$ \\
\hline 18 & $3 / 19 / 1987$ & Akko & Gombe & IV & Close to Akko & $1057^{\prime}$ & $1017^{\prime}$ \\
\hline 19 & $5 / 24 / 1987$ & Kurba & Bauchi & III & Close to Kurba & $1012^{\prime}$ & $1117^{\prime}$ \\
\hline 20 & $4 / 1 / 1988$ & Amauzu Ede-Oballa & Enugu & & & & \\
\hline 21 & $5 / 14 / 1988$ & Lagos & Lagos & $\mathrm{V}$ & Close to Lagos & & \\
\hline 22 & 9/1/1988 & Osererun Hills & Gombe & & & & \\
\hline 23 & $\begin{array}{r}4 / 1 / 1990 \\
\end{array}$ & Jere & Kaduna & $\mathrm{V}$ & & & \\
\hline 24 & $6 / 27 / 1990$ & Ibadan & Oyo & 3.7(ML) & Close to Ijebu-Ode & $0358^{\prime}$ & $722^{\prime}$ \\
\hline 25 & 7/11/1994 & $\begin{array}{l}\text { ljebu-Ode, Dan } \\
\text { Gulbi }\end{array}$ & $\begin{array}{l}\text { Ogun, } \\
\text { Zamfara }\end{array}$ & $4.2(\mathrm{ML})$ & Dan Gulbi & & \\
\hline 26 & $6 / 19 / 1905$ & Okitipupa & Ondo & IV & $\begin{array}{l}\text { Close to Okitipupa } \\
\text { Ridge }\end{array}$ & & \\
\hline 27 & $3 / 7 / 2000$ & $\begin{array}{l}\text { Ibadan, Oyo, } \\
\text { Akure, Okitipupa, } \\
\text { Abeokuta, Ijebu- } \\
\text { Ode, Shagamu }\end{array}$ & $\begin{array}{l}\text { Oyo, } \\
\text { Ondo, } \\
\text { Ogun }\end{array}$ & $4.5(\mathrm{ML})$ & Close to Okitipupa & & \\
\hline 28 & $3 / 13 / 2000$ & Benin & Edo & IV & $\begin{array}{l}\text { Benin City }(55 \mathrm{~km} \\
\text { from Benin) }\end{array}$ & & \\
\hline 29 & $5 / 7 / 2000$ & Akure & Ondo & IV & Close to Okitipupa & & \\
\hline 30 & $5 / 19 / 2001$ & Lagos & Lagos & IV & Close to Lagos City & & \\
\hline 31 & $8 / 8 / 2000$ & Lagos & Lagos & IV & Lagos & & \\
\hline 32 & $8 / 15 / 2000$ & Jushi-Kwari & Kaduna & III & $\begin{array}{l}\text { Close to Jushi-Kwari } \\
\text { Village }\end{array}$ & $0742^{\prime}$ & $1403^{\prime}$ \\
\hline 33 & $3 / 1 / 2005$ & Yola & Adamawa & III & $\begin{array}{l}\text { Close to Cameroun } \\
\text { Volcanic Line }\end{array}$ & & \\
\hline 34 & $3 / 25 / 2006$ & Lumpa & Niger & III & $\begin{array}{l}\text { Close to Ifewara } \\
\text { Zungeru Fault }\end{array}$ & & \\
\hline 35 & $7 / 1 / 1905$ & Saki & Oyo & III - IV & & & \\
\hline 36 & $7 / 1 / 1905$ & Abeokuta & Ogun & & & & \\
\hline 37 & $11 / 5 / 2011$ & Abeokuta & Ogun & $4.4 \mathrm{M}$ & Close to Abeokuta & & \\
\hline 38 & $9 / 12 / 2016$ & $\begin{array}{lr}\text { Kwoi, } & \text { Border } \\
\text { Communities } \\
\text { between } & \text { Bayelsa } \\
\& & \text { Rivers } \\
\text { (Igbogene) } & \\
\end{array}$ & $\begin{array}{l}\text { Kaduna, } \\
\text { Rivers, } \\
\text { Bayelsa }\end{array}$ & $2.6-3.0 \mathrm{M}$ & & & \\
\hline 39 & $\begin{array}{ll}9 / 5 / 2018 & - \\
9 / 8 / 2018 & \\
\end{array}$ & Mpape & Abuja & II - IV & & & \\
\hline 40 & $3 / 9 / 2019$ & Mpape & Abuja & & & & \\
\hline
\end{tabular}

Source: Compiled from Akpan and Yakubu (2010), Eze et al (2011), Tsalha et al (2015), and Nwankwoala and Orji (2018) 


\subsection{Materials and Methods.}

In order to define the tectonic fault lines, one can adopt two major approaches, the non-geodetic approach, and the geodetic approach.

\subsection{Non-geodetic Approach}

The non-geodetic approach involves the connection of the epicenters of previous earthquakes and tremors. Akpan and Yakubu (2010) adopted this method in their presentation of the Ifewara-Zungeru fault (figure 1). Eze et al (2011) further adopted this method in proposing possible fault lines in figure 2 . To define the fault lines using this approach, the epicenters recorded in Table 1 were plotted on a map of Nigeria using ArcGIS 10.2 and lines of possible faults drawn.

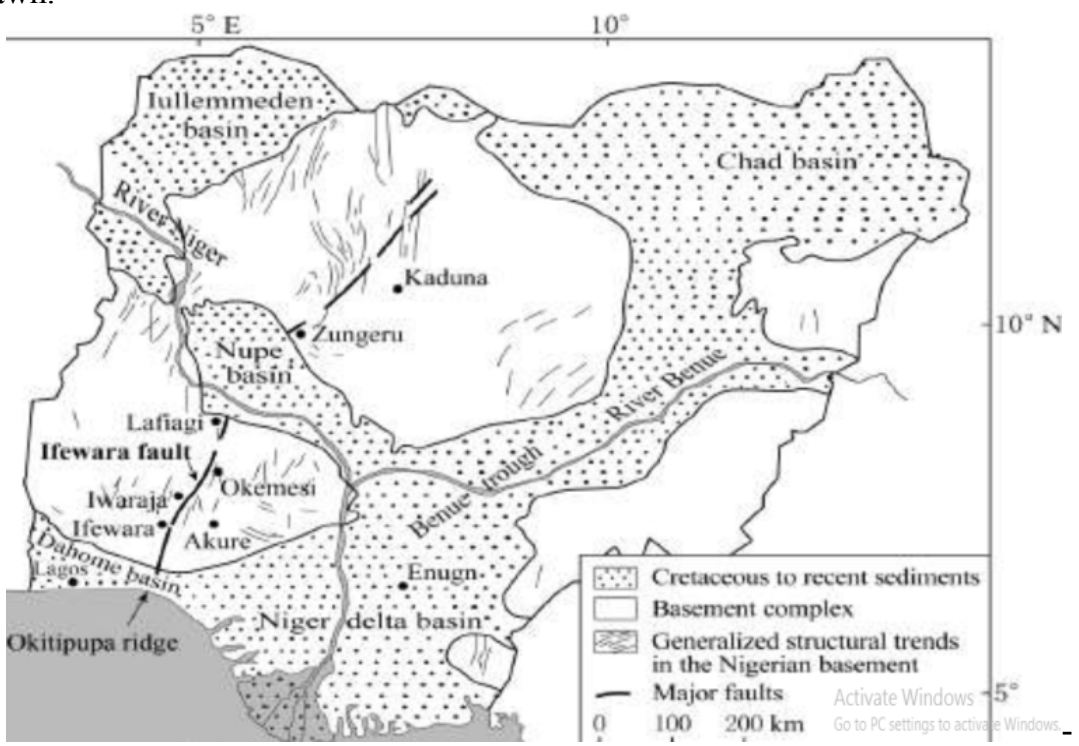

Figure 1: Map of Nigeria Showing the Ifewara- Zungeru Fault

Source: Akpan and Yakubu (2010)

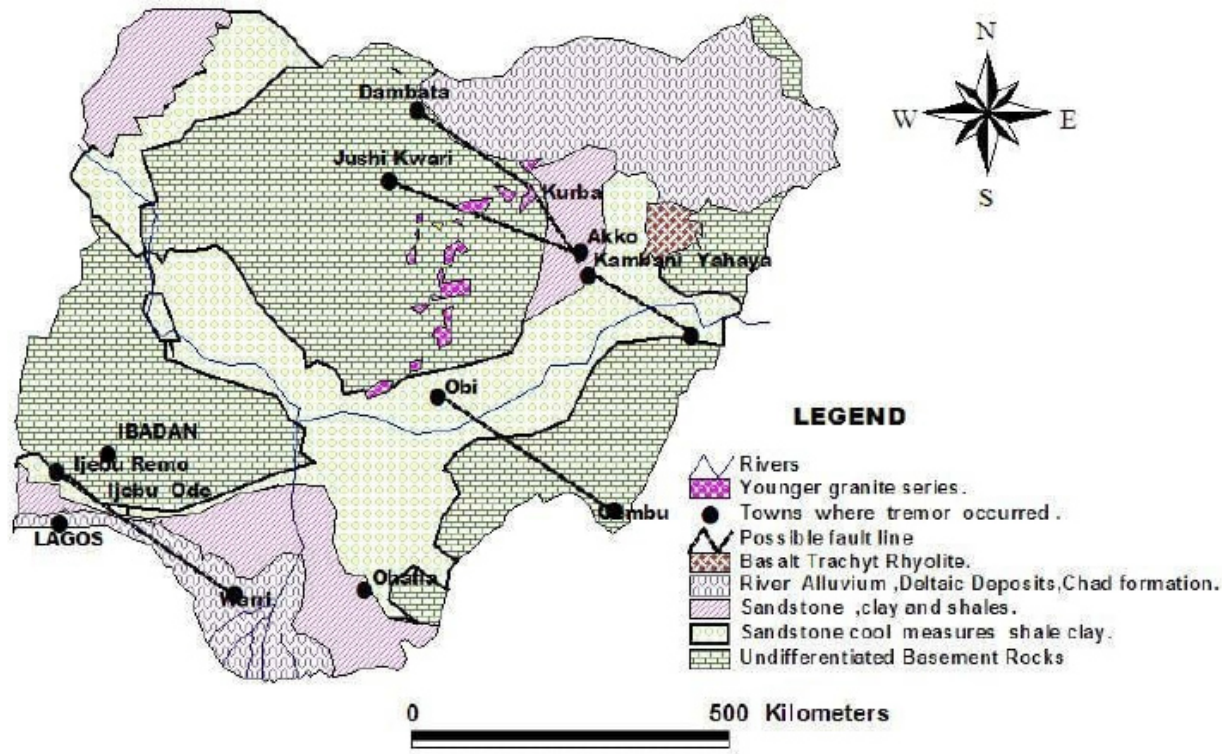

Figure 2: Map of Nigeria Showing Possible Fault Lines Source: Eze et. al. (2011)

This method is not particularly accurate because it cannot be used for effective planning of projects, since it is only hypothetical. A fault line that is not hypothetical should possess the ability to be geographically located and possibly marked off. This would make it possible to factor it in land use planning. 


\subsection{The Geodetic Method}

This involves the use of Geodetic techniques, such as Interferometric Synthetic Aperture Radar(InSAR), Global Navigation Satellite System(GNSS), and Satellite Altimetry, to monitor an area over time and the time series of the observation carried out in order to depict the velocities of the tectonic plates and the sharp difference in directions depicting the presence of fault lines. Aung et al (2016) and Wei, Jiang and Wu (2015) adopted this method in the study of Sagaing Fault in Myanmar, and the Kunlun Mountain Pass West (KMPW) Ms8.1 earthquake in 2001 and the Wenchuan Ms8.0 earthquake in 2008 in China respectively.

In this research, the GNSS technique was used, GNSS data from the Nigerian Continuously Observing Reference (COR) Stations for years 2012 through 2014 were acquired from the Office of the Surveyor General of the Federation (OSGOF). The sites used are ABUZ, BKFP, GCCT, CLBR, FPNO, FUTA, FUTY, GEMB, HUKP, MDGR, OSGF, RUST, ULAG AND UNEC. The GAMIT/GLOBK software package was used for the analysis. Ten International Geodetic Network (IGS) stations, DEAR, ABPO, RAMO, DARK, MELI, ASCG, MOIU, ZAMB, NOT1, BHR4, were used as stabilization sites. Their Receiver Independent Exchange Format (RINEX) data, Broadcast Ephemeris data (BDRC), and Orbit Ephemeris data were downloaded from SOPAC and CDDIS archives. These stations were chosen in a manner that ensured geometric balance for the stabilization. Ten were chosen in order to provide redundant measurements, in case one or two stations were to be excluded from the experiment. This method was found in Bawa, Ojigi and Dodo (2018), Stamps, Saria and Kreemer (2016), Aung et al (2016) and many other works.

\subsection{Result and Analysis}

Figure 3 shows a map of Nigeria with the locations of previous earthquakes and tremors used to identify the possible fault lines. From the spread and cluster of the previous tremors, three possible fault lines are proposed.

i. The Western Nigeria Fault Line: Thislineruns from the Atlantic Ocean, through Lagos, Ogun, Oyo, Kwara, Niger, Kaduna, Kano, and Jigawa states. It is akin to the Ifewara-Zungeru fault proposed by Akpan and Yakubu (2010). However, figure 3 and the records in Table 1 show that neither earthquake nor tremor was recorded in Osun State where Ifewara is located. It is in fact improper to insinuate that the fault line runs from Ijebu Ode through Ifewara as posited by Akpan and Yakubu (2010) when there is no epicenter in Osun rather close to Ibadan in Oyo State (1905 Tremor) and what was felt in Ile-Ife in 1936 the Ghanaian 6.5ML Earthquake with its epicenter in Akwapim Fault in Ghana.

ii. The Mid Nigeria Fault Line: This line also runs from the Atlantic Ocean, through Ondo (close to Okitipupa), Edo, Kogi, Abuja, Kaduna (Southern Kaduna), Bauchi, and Yobe states. This fault line is feared to be active, because the most recent tremors, as seen in Table 1, lie along this line. This is perceived to be the most active fault, owing to the recent Abuja Tremors.

iii. The Eastern Nigeria Fault Line:This fault line runs along the Abakaliki and Benue Troughs regarded by Nwankwoala and Orji (2018) as an example of a failed rift arm following the opening of the Southern Atlantic. They opined that extensional stress due to upwelling of magma beneath the region must have deformed the fault and created faults. After the extensional sets ceased, the weakened crust was covered with sediments over millions of years. This fault line run through Bayelsa (Igbogene), Rivers, Abia (Ohafia), Enugu (Ede-Oballa), Nassarawa (Obi) and Gombe States.

The other Tremor sites in Adamawa and Taraba states were as a result of their proximity to the Cameronian Volcanic line as shown in Table 1 for the Gembu and Jalingo tremors of 1982 and Yola tremor of 1984 and 2005. 


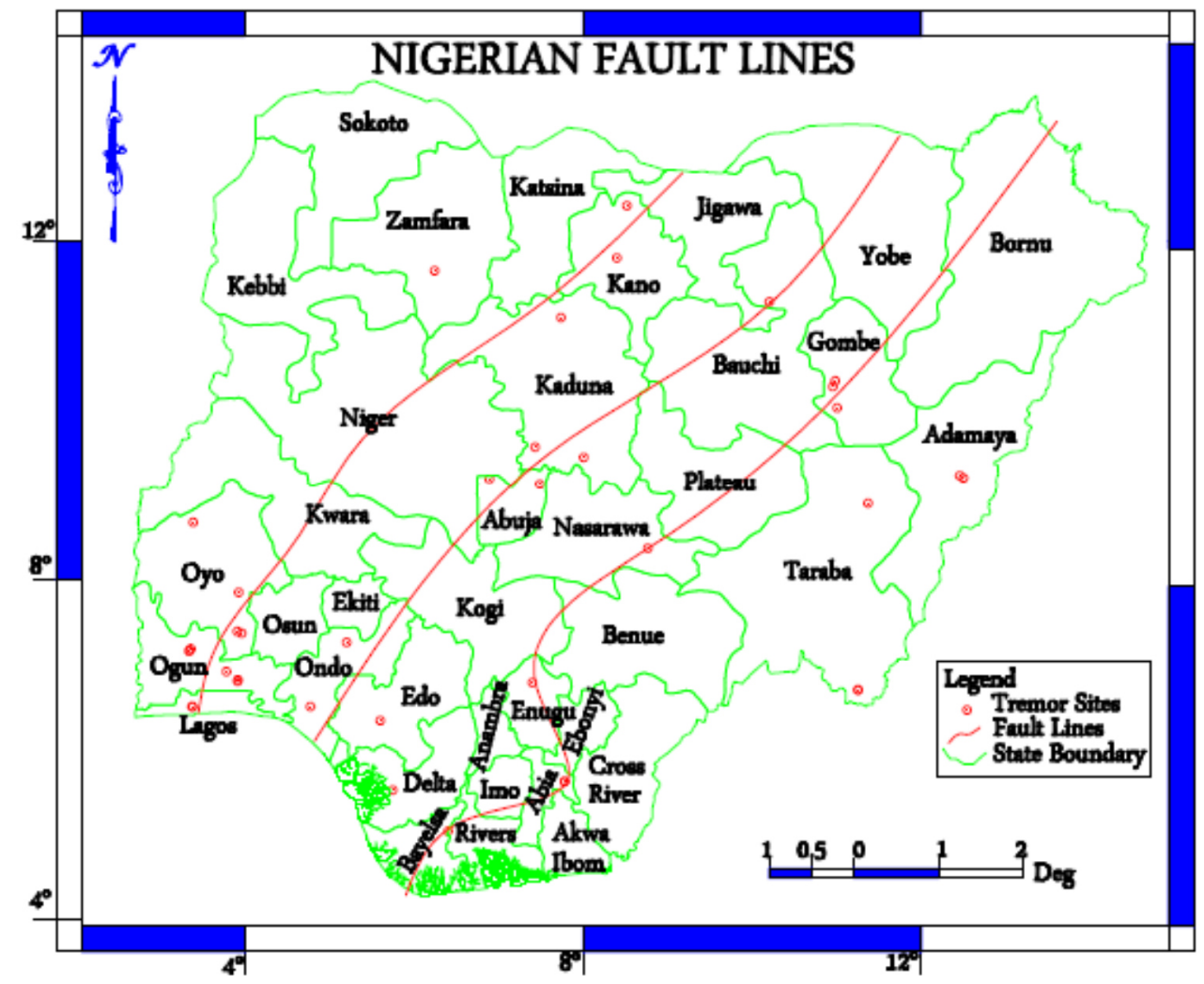

Figure. 3: Map of Nigeria Showing the Fault Lines

From the Geodetic analysis, the Mean Horizontal Velocity of Nigerian for the period was $22.5625 \pm 0.32583 \mathrm{~mm} / \mathrm{yr}$ East, $18.93 \pm 0.23417 \mathrm{~mm} / \mathrm{yr}$ North. This result was found to agree with Bawa, Ojigi and Dodo (2018) and Altamimi et al (2011). From the preliminary results, it was discovered that the MDGR site was giving outrageous values and it was regarded as an outlier and excluded from the experiment.

The Position Solution from the globk vel.orgfile was extracted and the Bearing and Distance covered by the NigNet Sites were computed from the change in Eastings (dE) and Change in Northings $(\mathrm{dN})$ and shown in Table 2 .

Figure 4 is the Velocity Plot for the experiment from 2012 to 2014. It is evident from Table 2and Figure 4 that although the direction of all the stations used for the Velocity plot are in the North East direction, the bearings of the motions are not the same. The stations with the most deviating bearings from the majority are the CGGT and the RUST stations at $67^{\circ} 5^{\prime} 37.8492^{\prime \prime}$ and $83^{\circ} 15^{\prime} 56.7288^{\prime \prime}$ respectively whose accuracies were also found to be poor as a result of verry few GNSS logs. However, it is interesting to note that the ten degrees $\left(10^{\circ}\right)$ range of change in bearing of the different displacements is wide enough to suggest possible presence of fault lines.

Table 2: Bearing and Distances of the Motions

\begin{tabular}{|c|c|c|c|}
\hline S/N & Site & Bearing & Distances \\
\hline 1 & FUTY_GPS & $52^{\circ} 57^{\prime} 50.8248^{\prime \prime}$ & $13.26575 \mathrm{~m}$ \\
\hline 2 & GEMB_GPS & $49^{\circ} 53^{\prime} 42.7956^{\prime \prime}$ & $12.95762 \mathrm{~m}$ \\
\hline 3 & CGGT_GPS & $67^{\circ} 5^{\prime} 37.8492^{\prime \prime}$ & $15.94302 \mathrm{~m}$ \\
\hline 4 & CLBR_GPS & $53^{\circ} 39^{\prime} 32.2956^{\prime \prime}$ & $13.48184 \mathrm{~m}$ \\
\hline 5 & ABUZ_GPS & $45^{\circ} 51^{\prime} 23.9472^{\prime \prime}$ & $19.89774 \mathrm{~m}$ \\
\hline 6 & HUKP_GPS & $46^{\circ} 58^{\prime} 17.4432^{\prime \prime}$ & $24.95676 \mathrm{~m}$ \\
\hline 7 & UNEC_GPS & $54^{\circ} 12^{\prime} 0.0108^{\prime \prime}$ & $13.33942 \mathrm{~m}$ \\
\hline 8 & OSGF_GPS & $54^{\circ} 17^{\prime} 1.4568^{\prime \prime}$ & $13.1856 \mathrm{~m}$ \\
\hline 9 & FPNO_GPS & $56^{\circ} 32^{\prime} 40.8552^{\prime \prime}$ & $14.55953 \mathrm{~m}$ \\
\hline 10 & RUST_GPS & $83^{\circ} 15^{\prime} 56.7288^{\prime \prime}$ & $8.549854 \mathrm{~m}$ \\
\hline 11 & FUTA_GPS & $47^{\circ} 39^{\prime} 21.6216^{\prime \prime}$ & $14.46029 \mathrm{~m}$ \\
\hline 12 & BKFP_GPS & $54^{\circ} 5^{\prime} 50.4852^{\prime \prime}$ & $12.81093 \mathrm{~m}$ \\
\hline 13 & ULAG_GPS & $55^{\circ} 59^{\prime} 26.3508^{\prime \prime}$ & $13.09045 \mathrm{~m}$ \\
\hline
\end{tabular}

It can be deduced that most of the stations along a particular line, appear to have the same direction of motion. UNEC (Enugu), FPNO (Owerri), CLBR (Calabar) and OSGF (Abuja) have bearings of 54'12'0.0108", 
$56^{\circ} 32^{\prime} 40.8552^{\prime \prime}, 53^{\circ} 39^{\prime} 32.2956^{\prime \prime}$ and $54^{\circ} 17^{\prime} 1.4568^{\prime \prime}$ respectively. ABUZ (Kaduna) and HUKP (Katsina) have the bearings 45 $51^{\prime} 23.9472^{\prime \prime}$ and 46 58'17.4432"respectively. FUTY (Yola) and GEMB (Gembu) have 52 57'50.8248" and 49 53'42.7956" respectively. Most interestingly, whereas the directions of ULAG (Lagos) and BKFP (Birin-

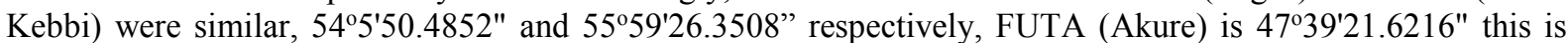
indicative of an existing (possibly active) fault between Lagos - Birin-Kebbi and Akure - ABUZ sections (the Ifewara - Zungeru Fault).

\subsection{Conclusion}

The evaluation of the Geodetic method of fault determination used in this experiment agrees with the NonGeodetic Method. It can then be concluded that there are indeed more than one fault lines in Nigeria. The Mid Nigerian Fault Line appears to be the most active fault line, given the recent tectonic activates around Abuja. This is closely followed by the Western Nigerian Fault Line given the date of the most recent tectonic activity along the line to be the Abeokuta 4.4M in 2011. The Eastern Nigeria Fault Line is adjudged the most inactive fault line. There is however a dire need to establish more than five times the number of COR Stations in Nigeria. The Data from those stations should be made readily available to researchers, as data availability was the greatest challenge for this experiment. New stations to be established, should concentrate around the three proposed fault lines to help in further investigations of tectonic activities within the country.

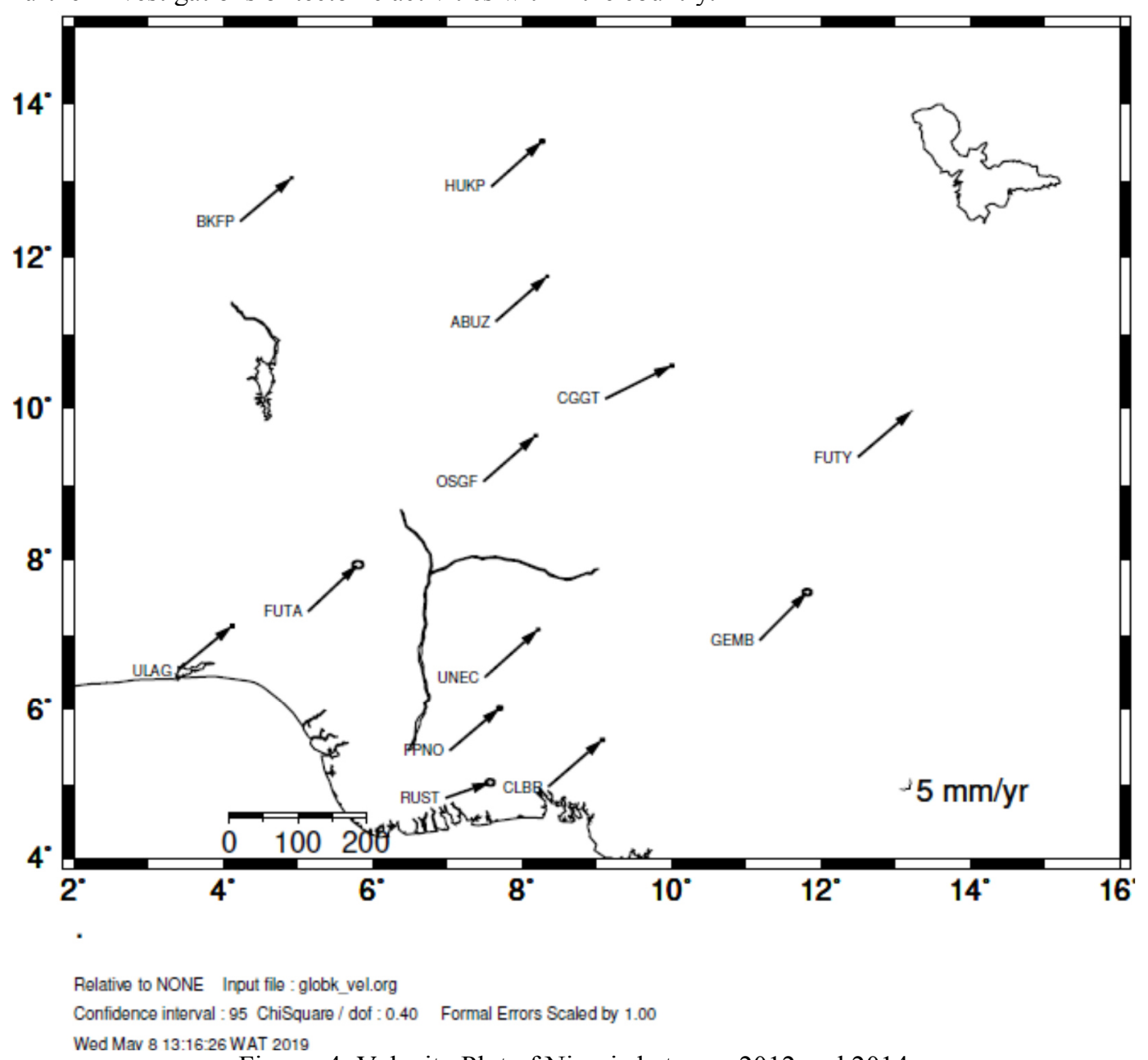

Figure. 4: Velocity Plot of Nigeria between 2012 and 2014

\section{References}

Afegbua in Orakpo E. (2017): Earthquake in Nigeria: Measures to Avert Devastating Impacts-Experts., Vanguard January 4, 2017. Online Version, https://www.vanguardngr.com/2017/01/earthquake-nigeria-measuresavert-devastating-impacts-experts/ Accessed 26 ${ }^{\text {th }}$ Nov. 2017.

Akkar S., Aldemir A., Askan A., Bakir S., Canbay E., Demirel O., Erberik A., Gülerce Z., Gülkan P., Kalkan E., Prakash S., Sandikkaya A., Sevilgen V., Ugurhan B., and Yenier E. (2010): Earthquake: Observations on Ground Motions and Building Damage. Seismological Research Letters 82(1)doi:10.1785/gssrl.82.1.42

Akpan O. U. and Yakubu T. A. (2010): A Review of Earthquake Occurrences and Observations in Nigeria. 
Earthquake Science. June 2010, 23 (3), 289-294. https://doi.org/10.1007/s11589-010-0725-7 Accessed 26th Nov. 2017.

Altamimi Z., Collilieux X., and Metivier L. (2011): ITRF 2008: An Improved Solution of the International Reference Frame. Journal of Geodesy 85, 457 - 573.https://doi:10.1007/s00190-011-0444-4

Aung P. S., Satirapod C. and Andrei C. O. (2016): Sagaing Fault slip and Deformation in Myanmar observed by continuous GPS measurements. Geodesy and Geodynamics 20167 (1), 56-63

Bawa, Ojigi and Dodo (2018), GPS Velocity Time Series of NigNet CORS. Nigerian Journal of Geodesy, 2 (2), $163-180$

Cetin, E., Cakir Z., Meghraoui M., Ergintav S., and Akoglu A. M. (2014): Extent and distribution of aseismic slip on the Ismetpas, a segment of the North Anatolian Fault (Turkey) from Persistent Scattered InSAR, Geochem. Geophys. Geosyst., 15, 2883-2894, doi:10.1002/2014GC005307.

Eze C L, Sunday V N, Ugwu S A, Uko E D and Ngah S A (2011), "Mechanical Model for Nigeria Intraplate Earth Tremors. Articles, Disasters, Management Theme", Earth Observation, Port-Harcourt, IEEE Oceanic Engineering Society.

Hackl M., Malservisi R. and Wdowinski S. (2009): Strain Rate Patterns from Dense GPS Networks. Natural Hazards and Earth System Sciences. Copernicus Publications on behalf of the European Geosciences Union. 17 July 2009. (1177 - 1187)

Ingolfsson O., (2008): Plate Tectonics and Continental Drift. Online Version. https://docplayer.net/24150854Plate-tectonics-and-continental-drift-jardsaga-1-saga-lifs-og-lands-olafur-ingolfsson.html Accessed 6th February 2018

Nwankwoala H. O. and Orji O. M. (2018): An Overview of Earthquakes and Tremors in Nigeria: Occurrences, Distributions and Implications for Monitoring. International Journal of Geology \& Earth Sciences, 2018 4(4) doi:10.32937/IJGES.4.4.2018.56-76.

Reilinger R. and McClusky S. (2011): Nubia-Arabia-Eurasia plate motions and the dynamics of Mediterranean and Middle East Tectonics.Geophysical Journal International186, 971-979. doi: 10.1111/j.1365246X.2011.05133.x Accessed 30 ${ }^{\text {th }}$ January, 2019.

Stamps D. S., Saria E and Kreemer C (2016), A Geodetic Strain Rate Model for the East African Rift System. Scientific Reports 2018 8(732) 1-8

Tsalha M S, Lar U A, Yakubu T A, Umar A K and Duncan D (2015), "The Review of the Historical and Recent Seismic Activity in Nigeria. IOSR”, Journal of Applied Geology and Geophysics, e-ISSN; 2321-0990, Vol.3, No. 1, pp. 48-56.

Wei W., Jiang Z., and Wu Y. (2015): Cognitions and Questions Regarding Crustal Deformation and Location Forecasts of Strong Earthquakes. Geodesy and Geodynamics 2015, x(x), $1-10$ http://www.jgg09.com/jweb_ddcl_en/EN/volumn/home.shtml 